\title{
Specters of Colonialidade: A Forum on Jacques Derrida's Specters of Marx after 25 Years, Part V
}

\author{
Carla Rodrigues* \\ Rafael Haddock-Lobo** \\ Marcelo José Derzi Moraes ${ }^{* * *}$
}

\begin{abstract}
Jacques Derrida delivered the basis of The Specters of Marx: The State of the Debt, the Work of Mourning, \& the New International as a plenary address at the conference 'Whither Marxism?' hosted by the University of California, Riverside, in 1993. The longer book version was published in French the same year and appeared in English and Portuguese the following year. In the decade after the publication of Specters, Derrida's analyses provoked a large critical literature and invited both consternation and celebration by figures such as Antonio Negri, Wendy Brown and Frederic Jameson. This forum seeks to stimulate new reflections on Derrida, deconstruction and Specters of Marx by considering how the futures past announced by the book have fared after an eventful quarter century. In this fifth group of contributions, three philosophers explore the specters of colonialidade, the specifically Brazilian legacies of Portuguese and European coloniality. Carla Rodrigues opens the dialogue by exploring the haunting and melancholy provoked by colonial forms of violence and shows how confronting Brazilian necropolitics sustains the Derridean legacy; Rafael Haddock-Lobo offers a meditation on the difficulties of being before the law and standing before specters as a means of being justly haunted by the others of European philosophy in Brazil; finally, Marcelo Moraes continues the theme of Europe as a specter-producing machine and invokes specifically the presences of indigenous and Afro-Brazilian political resistances with the aim of deconstructing coloniality.
\end{abstract}

Keywords: Derrida, Jacques; Brazil; translation; violence; necropolitics; Kafka, Franz; philosophy; race; coloniality; quilombos.

\footnotetext{
* Federal University of Rio de Janeiro (UFRJ), Rio de Janeiro-RJ, Brazil; carla.ifcs@gmail.com. ORCID iD 0000-0002-1421-5120.

** Federal University of Rio de Janeiro (UFRJ), Rio de Janeiro-RJ, Brazil; outramente@yahoo.com. ORCID iD 0000-0002-3983-7313.

*** State University of Rio de Janeiro (UERJ), Rio de Janeiro-RJ, Brazil; marcelojdmoraes@hotmail.com. ORCID iD 0000-0003-0086-5314.
} 


\section{Writing Around Ghosts}

Carla Rodrigues

translated by Thais de Bakker Castro

I start by evoking the concept of realist capitalism by Mark Fisher (1968-2017), the young English thinker who wrote an impressive diagnosis of our time starting from the question: 'is there no alternative?', which is the subtitle of Fisher's Capitalist Realism (2009). His argument uses the diagnosis of a shortening of the horizon of expectations, one of the consequences of what was identified as the 'end of history' about twenty years before the book was published, in the aftermath of the fall of the Berlin wall and the triumphant combination of liberal democracy and capitalism. The end of history would also announce the forgetting of everything that, in the past, stopped the fulfilment of this future in relation to which there was no alternative, to use Fisher's words. With that, a constant present is inaugurated, one that only announces its own repetition going forward.

Despite all the critiques he makes to Jacques Derrida, Fisher started to contest the premise of capitalism as a single fate by utilizing, among other elements, the notion of hantologie, a neologism proposed by the French-Algerian philosopher in Spectres de Marx: L'Etat de la dette, le travail du deuil et la nouvelle Internationale. Published in 1993, Specters of Marx was a mark in its time and, for many readers of Derrida, is a dividing line in his philosophy. ${ }^{1}$ My recourse to Fisher is moved by the haunting task of writing about ghosts, or, more specifically, writing about hauntology, a difficulty that starts with a problem of translation. With this neologism, Derrida is, among many other things, calling attention to the spectral and ghostly character of ontology, haunting being with non-being. In French, there is a homophony between ontologie and hantologie, impossible to reproduce in Portuguese. ${ }^{2}$

Fisher does not have the same problem of transposing the term into English - even though there is not a perfect homophony between hauntology and ontology -, because he has recourse to the use of the word 'haunt' as synonymous to the French hante that Derrida uses. When Anamaria Skinner translated Specters of Marx, she opted to use obsidiolo$\mathrm{gia}^{3}{ }^{3}$ which is a choice that, despite being faithful to one of the senses proposed by Derrida, I do not feel comfortable using since it would lead me to lose what is for me the most important thing in this debate: the critical reference to ontology. ${ }^{4}$ There are other translation attempts, like espectrologia ou assombrologia ${ }^{5}$ but none of them seemed to function in the same way as hantologie or hauntology, signifiers operated by Derrida and Fisher. ${ }^{6}$

When I discovered that Fisher's Spanish translator, Fernando Bruno, uses hauntología - in my opinion, following the idea that when it comes to a neologism in the language it is proposed, it may remain as such in the language it is translated to - I decided to run the risk of using hauntologia and its derivatives, like hauntológica/o, ${ }^{7}$ making an analogy to translation in the Argentinian edition (Fisher 2018), and keeping the weirdness of the term that maintains this article, therefore, in haunting. 
That is because, when he makes the proposal to work on the idea of hauntology, Fisher recuperates the unheimliche character of the term haunt. Hauntology as that which is unfamiliar (Freud 2019) interests me since, in this article, I am thinking in terms of the strangeness of a temporality that refuses the chronology of past-present-future. Perhaps there is really nothing more unfamiliar than our ghosts, too close and distant at the same time. I take the path of ghosts to speak of the colonial condition of being haunted by that which is not and could not be. To be a Latin-American haunted by not being European, to be black and haunted by not being white, to be indigenous and haunted by not being Portuguese, to be from the periphery and haunted by not being central, to be a woman haunted by not being a man, to be a homosexual haunted by not being heterosexual, to be transgender haunted by not being cisgender, and so on. From ontology to hauntology, would there be something peculiar in the experience of colonial haunting? To work around hauntology with the goal of making it an instrument to reflect about our relationship with time and with the colonial past that haunts us was what put me in conversation with (my) ghosts.

If it were possible to say that Derrida's thought revolves around a centre - which one cannot do, given deconstruction's character of refusing a system that constitutes itself around a foundational element - perhaps it would also be possible to propose that the notion of specter would assume this place. In a work that refuses topologies like centre, cornerstone or even the metaphorical heart, Derrida's commenters turn out to be more or less free to arbitrate a Derridean notion and work around it as if it were central. ${ }^{8}$ Specters of Marx has as one of its themes a debate with Francis Fukuyama and the critique of the end of history, here understood as linear and constant progress towards a finality. A modern and European notion, history points to a future to be conquered and to a past to be overcome, and, consequentially, forgotten. I cannot but register echoes of Walter Benjamin's 'On the Concept of History' (2005 [1940]) in all the debate around the progress of history, the critique of historical materialism and the messianic conception of a turn outside of progress as an inspiration to a debate around the relations between history and memory, also marked by the influence of Friedrich Nietzsche (2003) and his proposal to separate what to remember and what to forget.

Almost ten years after Derrida, Quijano (2014 [2001]) dedicates a paper to contest Fukuyama’s propositions with the suggestive title ‘El fin de cual historia?’ There, the Peruvian thinker too interrogates Fukuyama and points towards the Eurocentrism in the idea of an end of history, with the argument that it was already time to 'prepare another History, the one which will result from the great fights already in sight. This new history may be our History' (Quijano 2014 [2001]: 603). ${ }^{9}$ If the horizon of expectations that the future offers is only, and in large measure, a bettering of what already happened in the past, the past would be condemned to forgetfulness, the future to a mere repetition, and all historical narrative would be fated to fall into a nostalgia not only undesirable but also melancholic (Tupinambá 2018).

With the goal of refusing the identification between nostalgia and hauntology, Fisher mobilizes an argument that I recover here in an interested manner: 
It seems strange to have to argue that comparing the present unfavourably with the past is not automatically nostalgic in any culpable way, but such is the power of the dehistoricising pressures of populism that the claim has to be explicitly made (Fisher 2014: 32).

Besides this argument, Fisher operates with three distinct forms of melancholia: left melancholia, postcolonial melancholia and hauntological melancholia. ${ }^{10}$ Referring to Wendy Brown (1999), Fisher corroborates the diagnosis of the political scientist: the left is stuck in a structure of melancholic commitments of a dead past. 'Brown's left melancholic is a depressive who believes he is realistic', writes Fisher (2014: 30). After that, referring to Paul Gilroy (2005), Fisher identifies postcolonial melancholia as the negation of change, like the attachment to a fantasy of omnipotence, lost in undesirable and oppressive transformations. Refusing, like Fisher, these two forms of melancholy, I propose to think alongside Quijano, who is interested in the past not in the 'postcolonial' sense criticized by Fisher, but through his critical decolonial perspective, which he delineates with the concept of the coloniality of power (Quijano 2014 [2001]: 781). Starting from the understanding that Latin America's colonization produced a new global structure of labour control, with the invention of the idea of race and its articulation to labour division, Quijano proposes the idea of a 'return of the future', which I understand as an inventive mode of confusing the linear temporality that points us towards a future that will only be the repetition of the present. I identify in 'melancholic hauntology' and in the 'return of the future' two mechanisms that, each in its own way, establish another relation with temporality. I decided to approximate them to discuss, as a hypothesis, the localization of a hauntological aspect in Quijano and of a return to the future in hauntology, perhaps more in Derrida than in Fisher.

The return of the future is an aporia in Derridean fashion, a weird temporality in which the future is not ahead, but pointing towards alternatives that were being forgotten in a past condemned not to be remembered. In the words of Quijano, it is the creation of a 'parallel horizon of knowledge, of a non-Eurocentric rationality, which may also be a part of the future's horizon itself' (Quijano 2014 [2001]: 846). In my point of view, it is an invitation to visit our ghosts, in the sense of moving that which was never integrated. For that end, perhaps it is possible to find political and community practices that remained existing in the margins of progress or despite it, which makes me believe this re-encounter is different than postcolonial melancholia that looks for the time of 'before.'

\section{The police as a ghost}

Here, I want to move forward. Not in the direction of the future as a finality, but towards what I believe to be a necessary critique to police violence as one of the greatest inheritances of our colonial condition and of the constitution of the nation-state in continental Latin America. I would like to think through the spectral character of the police, its phantasmagorical violence, its hauntological operation of elimination of that which cannot be but a ghost, in name of the preservation of that which is, like the most violent aspect in 
the breach of the horizon of expectations, maximal indication of a constant present that only offers its infinite repetition. The element of police violence, disguised by the syntagma of 'public security', makes the coloniality of power work, integrating racism and the oppression of labour in strategies of domination. The police kill or arrest in penitentiary conditions similar to death in life and in both cases there is a naturalization of this death as a part of the life of the people to which this violence destines itself, as if dying were really the only destiny that the future can offer to those to whom the only existence attributed is hauntological. ${ }^{11}$

In the almost century-old 'Critique of Violence,' Benjamin (2011 [1921]) makes his critique work a movement of separation, which ends up helping to realize certain notso-sharp co-implications. The philosopher is interested in discerning the characteristics of natural law and positive law, of foundational violence and violence that maintains law, only to mention those that interest me the most here. In this movement, he identifies the maintenance of the juridical, statist and institutional ordering in a tripod of force, power and violence: militarism, the death sentence and the police. Benjamin realizes, for example, that the law's interest in having the privilege of the monopoly of violence is moved by guaranteeing its own existence, which makes the violence that inaugurates law present - even if purposefully hidden in the acts of law-maintaining violence. It is in the police that Benjamin localizes the more evident connection between the two types of violence: as foundational and as maintainer of law. Benjamin's critique of violence was followed more or less closely by other philosophers who confronted themselves with the barbarity in the heart of twentieth-century Europe, a barbarism that was allocated, or perhaps it may be said foreclosed, to the colonies. I cite a few examples:

The decisive difference between totalitarian domination, based on terror, and tyrannies and dictatorships, established by violence, is that the former turns not only against its enemies but against its friends and supporters as well, being afraid of all power, even the power of its friends. The climax of terror is reached when the police state begins to devour its own children, when yesterday's executioner becomes today's victim (Arendt 1970: 55).

In a normalizing society, race or racism is the precondition that makes killing acceptable [...] racism is the indispensable precondition that allows someone to be killed, that allows others to be killed. Once the State functions in the biopower mode, racism alone can justify the murderous function of State (Foucault [1976] 2003: 256).

[F]inally [the new governmentality] has to provide itself with an instrument of direct, but negative, intervention, which is the police [...] you can see that the old police project, as it appeared in correlation with raison d'État, is dismantled, or rather broken up into four elements: economic practice, population management, law and respect for freedoms, police (Foucault [1978] 2007: 354). 
Let us take the example of the police, this index of a ghostly violence because it mixes foundation with preservation and becomes all the more violent for this. Well, the police that thus capitalize on violence are not simply the police. They do not simply consist of policemen in uniform, occasionally helmeted, armed and organized in a civil structure on a military model [...] By definition, the police are present or represented everywhere there is force of law [loi]. They are present, sometimes invisible but always effective, wherever there is preservation of the social order (Derrida 2002 [1989]: 278).

It may not be necessary to establish when the specters started to function in Derrida's philosophy, but for the same reason it may be necessary to remember that Specters of Marx was being gestated, in some measure, during the two conferences that compose 'Force of Law' (Derrida 2002), which took place between 1989 and 1990, not only in the heat of the events in Berlin that marked the end of the twentieth century, but also, and above all, through a discussion of the previously cited Benjaminian propositions in relation to the foundational violence of positive law and, more broadly, to the constitution of the modern nation-state.

Updating the tripod upon which Benjamin identifies the violence of law - militarism, politics and the death sentence - to the Brazilian context, we may compare the Armed Forces, constituted by the Army, the Navy and the Air Force, to militarism, which is joined by the three police forces attached to the three spheres of government: at the federal level, we have the Federal Police and the Special Task Force, evoked by the Presidency of the Republic in circumstances classified as extraordinary; in the 27 states, the Military Police act with the function of so-called policing and public security; and at the prefectural level, the municipal guards grow, progressively endowed with police power. In relation to the municipal guards, there is a juridical debate regarding the unconstitutionality of granting them the right to bear firearms, which seems inevitable in the face of a national pro-weapon policy. All of this does not even consider the contingents of private security that act in public spaces. All these security forces are only the authorized ones and do not include the militias or parallel powers, progressively growing in the streets and in penitentiaries. ${ }^{12} \mathrm{At}$ this point, it is worth evoking Achille Mbembe and his articulations between war and the colonial condition:

War is no longer waged between armies of two sovereign states. It is waged by armed groups acting behind the mask of the state against armed groups that have no state but control very distinct territories; both sides having as their main targets civilian populations that are unarmed or organized into militias [...] Military operations and the exercise of the right to kill are no longer the sole monopoly of states, and the 'regular army' is no longer the unique modality of carrying out these functions [...] Urban militias, private armies, armies of regional lords, private security firms, and state armies all claim the right to exercise violence or to kill (Mbembe 2018: 139). 
The scene described by Mbembe is not at all unfamiliar to us. To Mbembe, the colony represents the place in which sovereignty fundamentally lies in the exercise of power on the margins of the law, a place in which peace tends to assume the face of a 'war without end.' The colonies are zones where war is alternated with disorder to operate all kinds of violence attached to the state of exception; colonization is, therefore, the exercise of sovereign power in the name of supposed civilization against barbarism, which is also an argument for the constitution of the nation-state through congregation and segregation. With the notion of a 'war without end,' Mbembe supplies me with a tool to think about contemporary violence as a hauntology of the European colonial enterprise's violence, which perpetrates itself - phantasmagorically - in daily practices that critically separate those who can only live in the margins of the law, as targets of the violences of foundation and maintenance, and those who institute the law with the end of detaining a double power, that of being the law and instituting those who will be abandoned at the margins of the law. Would it be possible to comprehend all the juridical, institutional and economical apparatus that sustains the violence necessary for the nation-state to exist as hauntological?

The ghostly aspect of belonging to the nation-state was performatized, in the USA, by a group of Latin American immigrants who translated and sang publically the national anthem of the country in Spanish, a revindication of rights as immigrants that was discussed by Judith Butler and Gayatri Spivak in Who Sings the Nation-State? (2018 [2011]). ${ }^{13}$ The gesture reminds me of Derrida's aporetic formulation (1996) regarding the articulation between nation and mother-tongue: I only have one mother-tongue and this tongue is not mine, a postulate that summarizes his condition as a French-Algerian, the hauntological hyphen indicating that he is neither French without being Algerian, nor Algerian without being haunted by the ghost of French colonization.

Finally, I would like to think about the distinction between the foundational and maintaining violence of law in the understanding of colonial violence as necropolitics. It is also of interest to me to try to distinguish the elements of violence that are common to the constitution of all nation-states and those that are peculiarly connected to the colonial experience. Although Benjamin directs his critique to the forms of violence that constitute the European nation-state in that historical moment, here I am taking the liberty to apply them to the constitution of all nation-states, considering as a hypothesis that the colonial experience is haunted by one more form of violence, besides the foundational and maintaining violence identified by the German philosopher. It may be necessary to consider that, through the war without end, there is a permanent process of reproducing new colonizers and new colonized.

If this diagnosis is of value as a hypothesis, here we would be in constant need to renovate the law and erase it immediately - one more turn in the Kafkian story, a turn that would mark the difference between the nation-state formed through congregation, like Benjamin's Germany, and the nation-state formed through colonization. In 'Before the Law' (Kafka 2012) the protagonist is waiting for the door of the law to open, and it never opens for him. There is law, but it is inaccessible. In the colonial experience, the doors of the law are opened and re-opened to demarcate the place of outlaw, to affirm sovereignty 
or the coloniality of power, which is strong precisely because it always acts in the margins of the law.

In Brazilian-style necropolitics, it is necessary to perceive at least three moments. In the first, the foundation of law, the access to law is promised; in the second, this promise is postponed through the violence that maintains the law. Lastly, in the third moment, the access to law is made impossible not only so that the privilege of the violence of the law remains in the hands of those who detain juridical apparatuses, making law unachievable, as Benjamin identified, but also in order to promise again, thus feeding the war without end in the name of a single law which will come as violence. It remains a question to comprehend which haunting aspect of this violence is not limited to a single source anymore - State, capital or law - or to the combination of those three sources, emerging from anywhere against anyone, as only ghosts have the power to do. In the daily exercise of the coloniality of power, which I take here as the most oppressive form of domination of the nation-state, the goal is to erase traces of the colonized, who survive in a hauntology, as a ghost of themselves.

\title{
Before the Specters - A Task That Is To-Come
}

\author{
Rafael Haddock-Lobo
}

It is 16 August 2004. Fifteen years ago Derrida came to Brazil and offered us one last conference. At that time, deconstruction was a starting point from which the philosopher provoked us not detain ourselves exclusively before the philosophical controversies of the West. His philosophy enables us to try to understand our problems from the uniqueness of our colonial situation. ${ }^{14}$ Three days later, the French newspaper Le Monde published an interview with Derrida. There are moments of the interview when Derrida (2007: 40) assumes that the task of deconstruction, since its apparition in the sixties, would be a very intense critique of colonization:

Then also, since the very beginning of my work - and this would be 'deconstruction' itself - I have remained extremely critical with regard to European-ism or Eurocentrism [...] Deconstruction in general is an undertaking that many have considered, and rightly so, to be a gesture of suspicion with regard to all Eurocentrism. 
October 9, two months later, now we find Derrida among the specters of the philosophical pantheon. And perhaps the same thing that he possibly teaches is what helps us to understand the task of standing 'before the specters' in a better way. To understand the task, both haunting and spectral, it is necessary - first of all - to present what it means to 'stand before' Derrida. Then we can think about which would be the philosopher's place 'before the specters.'

Derrida pays tribute to Lyotard at the Cerisy colloquium of 1982 (see Derrida 1992a). He pays his tribute by presenting a reading of a tale entitled 'Before the Law' which was written by Franz Kafka and afterwards added to The Trial. I summarize the story here (see Kafka 2012: 3-4): 'Before the Law stands a doorkeeper', writes Kafka. Then, he tells about a countryman who goes to the city and prays for admittance to the Law. He is detained by the doorkeeper, who tells him: 'it is possible, but not at the moment.' The fact that the gate remains open, as usual, gives him hope that one day he will have the chance to get inside. The eager expectation that the law will be accessible to all is what makes the man remain still on the stool the doorkeeper gave him for days, months, years. The countryman's attitude goes from muttering as a child to cursing like an old man. And when he is close enough to death he asks the doorkeeper the fatal question - 'at length his eyesight begins to fail, and he does not know whether the world is really darker or whether his eyes are only deceiving him. Yet in his darkness he is now aware of a radiance that streams inextinguishably from the gateway of the Law.'

'Everyone strives to reach the Law' questions the countryman: 'So how does it happen that for all these many years no one but myself has ever begged for admittance?' The doorkeeper shouts his answer, exhaustedly: 'No one else could be admitted here, since this gate was made only for you. I am now going to shut it' (Kafka 2012: 4).

In the book that Max Brod grafted on his friend's work, Josef K. - the slandered protagonist who is also tried - hears the story in question from the mouth of a priest, on the occasion that he is visiting the cathedral. K. finishes listening to the priest's account. So, he suddenly says: 'the doorkeeper deceived the man' (Kafka 2009: 155). In this way, we all stand with the countryman. We are seeking a justice that we can always access, a place where we always find the doors opened. For us, to be 'before the law' should be like 'standing before' an open door - inviting, affordable and universal for anyone and anytime. The thought about being 'before' the others is an endless task... We are facing the very aporia of the blocked way, which makes us angry as children or grumbling like elders. And that's what happened to the countryman, sitting all his life on a stool kindly provided by the doorkeeper.

But $\mathrm{K}$. is warned by the priest about making a hasty judgment. There is the doorkeeper who also 'stands before the countryman', and he always worked with zeal. At the beginning of the report, he tells the countryman that 'at the moment' he cannot enter. At the end of the story, he says that the entrance was for him and no one else. In the words 
spoken by the priest of Kafka and Derrida none of this would constitute a contradiction... So, what can we learn? That seems to be Derrida's (1992a) question. If we are thinking about the law of Kafta as a law of the real we may also think that the door before which we settle is tradition as a legacy to us. In other words, a promise of access is always made, someday a reading to come, a meaning to be reached, a perfect interpretation. However, the word in question always seems kept as a 'not at the moment' addressed to us all the time. In whatever way, as the doorkeeper tells us, this door is ours alone. That calls us to try to enter in a unique way, by a reading, something of an interpretation, until one day we can see an unquenchable glow in the background, distant but before us.

To understand the real does not mean to walk through the door as the countryman would like. Really, there is no justice, no reality, there is nothing - only other doors secured by other doorkeepers. So, in a double gesture, the philosopher is - at the same time - a doorkeeper and a countryman, wanting to enter the law and guarding it, 'in front of the law': that's where the philosopher must endure his undecidability. This is the only way he can remain true to the uniqueness of the spectral summons addressed to him. In the end, he knows that a door will never be crossed because this is the law of the specters.

\section{II}

In April 1993, just a decade later, the conferences compiled in the book Specters of Marx seemed to complement the philosopheme in which I stopped. After all, what would be the philosopher's task when he is 'before' the specters, or with the specters 'before' him?

Derrida is sitting on his stool, next to the door. He is a guardian to both of them. In this position, he teaches us that the philosopher's task consists in a kind of invocation, acceptance and consenting of every otherness that appears. Things happen like this because the logic of apparition is the same as the event. We never know what is about to come.

To understand the philosophical gesture from which Derrida intends to depart we begin with a presentation of the triple meaning to which the author introduces us: a meaning for the term 'conjuration' in Specters of Marx. First, a conjuration is a conspiracy - made by an oath - against a power that is taken as superior. A conjuration is also an evocation or summoning of a spell or spirit. Finally, the conjuration would be the exorcism itself.

Thus, in this threefold meaning, or in the oath that conspires - in the spell or an invocation to exorcism - the philosophy remains, despite its obsession with removing obsessions. It's haunted before a 'real' made of multiple senses and possibilities that escape objective reality. Philosophy does not support what it does not realize. At the same time, philosophy believes that it must account for everything that exists. In a combination of arrogance and fear, it cannot stand anything that differs from itself. As such, philosophy is waging an insane battle to exorcise the spectrality from specters, so they can sound familiar. Calling it analysis, interpretation, classification, demonstration, deduction, description or synthesis, philosophy is afraid of appropriating the term that best presents the philosopher's task: the speculation or reflection. 
It arose from and into amazement. So, it cannot become the instance contrary to astonishment par excellence. First of all, philosophy should be the mirroring of the world, from the same real that, spectrally, it shows itself to us as a formless apparition, without any precision, reflected in some old frameless mirror. It is in this sense that Derrida (1994b: 221) writes:

He [the philosopher] should learn to live by learning not how to make conversation with the ghost but how to talk with him, with her, how to let them speak or how to give them back speech, even if it is in oneself, in the other, in the other in oneself: they are always there, specters, even if they do not exist, even if they are no longer, even if they are not yet. They give us to rethink the 'there' as soon as we open our mouths.

It is undeniable that our knowledge does not encompass the real. In a different way than modern rationality intended, we can no longer suppose that we subdue the real. And what was claimed only as a statement of superiority, as universal reason, as a way of thinking superior to the others, shows the intention of finally placing Europe in a position of superiority to all other nations of the planet - gnosiologically, ethically and politically. Philosophy can no longer be an epistemicide with methodology.

Remembering the ghost of the father, Hamlet's phantom, Shakespeare's phantasm, Marx's specter and Derrida's spectrum, we realize that being before the ghost seems to be a fundamental task that we learn from and in haunting. We learn from haunting to the extent that it is about a hetero-didactics, for which we cannot be prepared. There is no alphabet book or multiplication table to help us. And we learn in haunting, because there is not a present experience that can be formulated in theorems and understood later. That is, there is no result or solution - what anyone can learn happens in the encounter with the permanent unknown.

From a time that assumes itself to be haunted by specters, a new ethics and a new politics emerge. We are referring to an ethics and a politics that will help us to elaborate another justice and another possible community, without any of them being thought in the light of calculation or prediction. In an interweaving of past, present and future, this time refuses to think of the past as a present that is gone and about the future as a present to be. It unmakes temporality present and, by turning it into a spectrum, whether in a past to come or a future that has passed, can - and only it can - open us to the experience of 'being with' the ghosts, or with 'certain others who are not present, nor presently living, either to us, in us, or outside us' (Derrida 1994a: xviii).

This philosophy which is more than itself marks what is 'proper' to philosophy - of any and all philosophy. It consists of the same ethics and politics that Derrida talks about. It is with the intention of avoiding the fall into the spell cast by tradition that Derrida (1994a: xviii) tells us:

It is necessary to speak of the ghost, indeed to the ghost and with it, from the moment that no ethics, no politics, whether revolutionary 
or not, seems possible and thinkable and just that does not recognize in its principle the respect for those others who are no longer or for those others who are not yet there, presently living, whether they are already dead or not yet born. No justice [...] seems possible or thinkable without the principle of some responsibility, beyond all living present, within that which disjoins the living present, before the ghosts of those who are not yet born or who are already dead, be they victims of wars, political or other kinds of violence, nationalist, racist, colonialist, sexist, or other kinds of exterminations, victims of the oppressions of capitalist imperialism or any of the forms of totalitarianism.

So, these are the others, the ones the philosopher needs to 'stand before.' And it happens at the same time that he wants to enter this ghostly real that haunts and invites, wanting to taste the secret no matter how, he must be one of those who, no matter what, defend such a secret. We are talking about the secret that tells that there must always be a secret and that the real will always escape our speculations. So, this is the reason why the fairest speculation in the world will never be that which is only seen in the mirror, or the one that believes the world is only what appears in its reflection there. But it is in what is displayed in the distortion, in the broken glass scattered on the floor, in the metals twisted by time or in the eyes of any living being, human or animal, where you see not only unity and identity, but the multiplicity and difference which constitute the real itself, without any possible totality.

Like the ghost of Hamlet's father, the real haunts us through people, books, animals, landscapes and thoughts that call us, and to which we can only answer when we face them and present ourselves, even though our whole body trembles at the haunting, realizing that some strange mirroring, dissymetric, is created in this being before these others. 'Spirits. And one must reckon with them. One cannot not have to, one must not not be able to reckon with them, which are more than one: the more than one/no more one', says Derrida (1994a: xx). It's a strange formula. Specters are always more than one (they never perform alone, they are always accompanied, as horror movie fans know very well). At the same time, they're always less than one (not one more - they will never form a unity, will never form an outlined and closed community, they will never fit into a concept). They are multiplicity itself and also absolute singularity at the same time, with one forceful action. It is before this double presentation of the specters that we also are both the countryman and the doorkeeper at the same time.

\section{III}

I would like to present some of the current concerns that emerge from Jacques Derrida's provocations in order to try to complete these pages. So, I finish the text trying to give an answer to the question of what would be the philosopher's task before the specters in Brazil. 
To start responding - I am already anticipating that I answer without answering, because my double gesture here means that I want to answer, but I want to answer at the same time as I say 'not at the moment' - I go back to 'White Mythology,' published in 1971, where Derrida (1982: 213) denounces that metaphysics is a specific form of mythology: 'Metaphysics - the white mythology which reassembles and reflects the culture of the West: the white man takes his own mythology, Indo-European mythology, his own logos, that is, the mythos of his idiom, for the universal form of that he must still wish to call Reason.' In other words, metaphysics rises as an antipode of myth, having its mythological status disguised precisely in the war that it declares. First of all, what Derrida indicates is that we must think about metaphysics addressing its geographical and historical constraint. We are referring to a knowledge that is born in a certain region of the globe at a given time. In the second place, we need to remember that it is the same mystical foundation that authorizes both myth and metaphysics to present themselves as truths. The proclaimed authority of both always refers to their own mythologies.

However, unlike other myths, white mythology needs to get down and denounce all the other knowledges that come before it - or those that it cannot control - making the most childish claims and detractions regarding other philosophies that were not born in the noble cradle of the West. That is, this European mythology dresses itself with the mythical garments of 'reason.' And now, dressed up as something different than a myth, in an absurdly fictional move, it affirms its own myth as a reverse of the myth, as a rival and higher in status.

This is really sad, not only because of its obviously epistemicidal character, allergic to alterity, but also for depriving itself of the beauties that the West would have, if it claimed its own mythology as mythos. I quote Derrida (1982: 213) once again: 'White mythology - metaphysics has erased within itself the fabulous scene that has produced it, the scene that nevertheless remains active and stirring, inscribed in white ink, an invisible design covered over in the palimpsest.' The authoritarian and violent gesture of the West is in the statement of its whiteness as a transparency, as universal and neutral, the absence of colour. The white ink from what the history of philosophy writes has many aspects that, as people living in the southern hemisphere, we need to avoid. The whiteness that means purity, although presented as haughtiness, means nothing but its own greatest fragility, and because of its sensitiveness it avoids contact with the other, to prevent impurity. And so it loses all the possibilities of playing a game, finding new things and inventions. Its so-called colourlessness is needed as neutrality and universality, to assure itself of its assumptions, and denounce all philosophy of colour, all impure knowledge - brown, black, yellow or red. Its white ink composes the writing of semen and seed, because besides its whiteness it is also manly, masculine, and wants to inseminate any and all surfaces over which it ejaculates - because it carries the imperative of the conquest in aversion to the other, the catechesis, not to mention murders and rapes.

Its fabulousness faded, it was too white. Consequently, it was pale, unappealing, resentful and envious of the colour and joy of other mythologies. European mythology announces itself as a global destination with its monotheism, monogamy and monotony. 
Nevertheless, upon arriving at our lands, so coloured by the original inhabitants of what we call Brazil - some of them came with the also white and pale caravels - this mythology kept trying to make its whiteness persevere here with its fake purity, even amidst its notorious underdog condition. It was not seduced by the many colours of the beaches and woods, people, birds, fruits and fishes that lived here. And even less for those who, even dark skinned, were kidnapped from their lands by the same heroic and explorer ships. Amid a unique multiplicity of colours, race, ethnicities, cultures, images, sexes, genres, gestures, landscapes, gods, animals and plants, from where it could draw a unique mythical-philosophical power, it preferred, in the universities and educational institutions, to preserve its purity.

It is in this sense that the task of deconstruction and colonial criticism come together in the same gesture. And it is in this sense that the philosopher, standing on Brazilian soil, needs - in the name of this multitude of specters exorcized by the university and erudite knowledge - to let himself be haunted and, more, to let himself be the one who learns to summon them.

Therefore, to stand before the specters in Brazil does not mean to turn your back to the European tradition, since it is in front of us, both constituting and haunting us. But, yes, we must make it smaller and compel it to live with the differences, from which it runs so fast because of its gigantic ego - as well as its difficulty in sharing spaces with other spectral manifestations. It is just like that, that in our forests Heidegger may find indigenous and African gods, and that the flanêur that we find in Benjamin, wandering around, may encounter tramps, hookers and pimps, that Ulysses' seas, the seas of the Greeks, the Portuguese and the English, may shelter the infinity of mermaids that inhabit these lands.

Maybe they were meant to be sung, and not made to be read, as Nietzsche would like and as Maria Bethania does. Maybe in the rhythm of the atabaques and rattles, and coloured with annatto paint or by our Carnaval makers, this other mythology that belongs more to us may arise - only it - without nationalism, without an identity of its own, with no property at all. And by the way, because of its beautiful and necessary precariousness it could, next to Derrida, and so many others, welcome the very philosophical voices of Estamira, Luísa Mahin, Nego Bispo, Leci Brandão, Mãe Beata de Iemanjá, Davi Kopenawa, Professor Agenor, Dona Ivone Lara and so many other specters, male and female, that we can summon from now on... 


\section{Colonial Phantasmagoria: The Return of the Specters}

Marcelo José Derzi Moraes

translated by Bruna Holstein Meireles

The French-Algerian philosopher Jacques Derrida left us many lessons, lessons of scripture, which are spectral lessons. One of those lessons of scripture lies in his book Specters of Marx, which we can understand as: one ought to live with ghosts. And it is under that reality that haunts us, as heirs to the colony, that we here think his spectral lesson (Haddock-Lobo 2019a). From this lesson, we understand Europe as a specter-producing machine, starting with its own projection. To put it differently, Europe is its own specter.

In order for us to continue in the potency of the Derridean inheritance, we must consider the spectral dimension that inhabits our reality. One must understand that we will speak of specters and of spectral effects. Considering that Europe forged itself as specter, it also forged thousands of specters that would return in the form of haunting. We will start from a possible first specter, which is Europe's centrality in world history. In centralizing itself in space and time, Europe has forged its first specter in its attempt to secure a spirit, that is, the spirit of the West. However, in forging this centrality in the globe, Europe created other specters, the specters of marginal peoples. That limitrophy will reinforce those margins' borders, creating a violent landscape of what is central and what is marginal. Thus, from the world's centre, Europe, no longer specter, will present itself as the irradiating spirit of light, of the light of reason, of the light of faith. Europe as the world's beacon that will enlighten the peoples of night and darkness. That, therefore, is the first European myth, one of the first moments in which Europe forges itself and its specters.

One must consider that the act of forging has a pharmako-logic character, meaning that forging holds at least a two-fold meaning. The act of forging is spectered by its opposite just as by other possibilities. To put it another way, at the same time that forging is constituting, creating, preparing, engendering, and generating; forging is also falsifying, inventing, concealing, counterfeiting. In light of this, we can gather that in every attempt to forge Europe's spirit, the European, as he created, conceived, also concealed and falsified something. That is, the European spirit is indeed a specter, one that, neither truthful, nor false, nor alive, nor dead, is and is not oneself.

That logic of creation and concealment did not simply stop among them and within their territory. From the colonial invasions onward, the European has created or counterfeited thousands of specters, producing at the margins of the world, at the margins of Europe, a phalanx of specters that would be conjured before haunting and terrorizing Europe. Hence, the European has forged the Americas, the Orient, and Africa, without foreseeing that one day those specters would return and resist colonial violence.

America (or Abya Yala, Tawantinsuyu, Anahuac, Pindorama according to societies that have lived here since well before the European invasion) was founded by violence, a violence that was physical as well as spectral. The founding of nation-states in the Americas presupposes that there was nothing here but savages prior to the Europeans' arriv- 
al. Therefore, the Europeans produced a narcissism and an ethnocentrism impossible to measure. The 1492 landing marked the arrival of death, of death's specter. Indeed, it would be more adequate to say: of a phalanx of specters. Among those ghosts and specters, there arrived not only European men, but a whole range of values, ideals, ways of living, models, concepts, thoughts, practices, arts, religions, sciences, etc., all committed to a becoming that would repeat and re-found itself until the present day, seeking to maintain that supposed first foundation.

The founding of nation-states conjured those who lived here previously, obliterating, murdering, and neutralizing their lives and cultures (see Derrida 1992b). Accordingly, the Europeans here established thought that they would found a new world, a new spirit. That spirit, forged with fire and the blood of hundreds of indigenous peoples of different ethnicities, would finally mark this region as Latin America. However, the European seemed to have forgotten that his own history is a history of ghosts, that is, the Europeans have forgotten that we live with ghosts. The Europeans here installed did not count on the specters of indigenous peoples' ancestry who did not accept enslavement and ethnocide, and who today still fight against colonization. Even before so much blood, death, rape, and destruction, the specters of those who here lived still resist. The spectral resistance of an ancestral spirit's endurance reveals itself in the bodies, minds, languages, rocks and cultures of what has become America. To the colonizer, there remains the disappointment of not being able to catch up to a pure people. The European was doomed to see and live the counter-colonization of Afro-descendent, indigenous and mestizo' peoples that have conjured the European who here tried to remain. To put it differently, they did not count on that new spirit being everlastingly haunted by the ghosts of the Aymara, Guarani, Quechua, Inca, Maia, Nhambiquara, Cherokee, Apache, Krenak, Bantu, and Nagô peoples, among hundreds of other societies that would permanently mark that new European spirit.

The ethical forgetting of living together with ghosts as enacted by the European man led to even more problems, for it was not enough to invade, enslave, murder, and colonize those lands and their peoples, it became additionally necessary to kidnap peoples from other places, from other regions. That said, the colonizing European man kidnaped black men and women from several regions in Africa and enslaved them so as to continue their project of forging that new spirit that was to come. In enslaving and kidnaping the Africans, ever since his arrival in Africa the European was the face of death, of death's ghost. The Europeans left Africa and crossed the ocean, leaving traces of death, conjuring specters in a trail that sunk into the ocean. As they arrived in what they called their colonies, the production of specters would not end, and beyond enslaving and kidnaping the Africans there was a constant production of death. In this sense, colonization, the colonial system, the maintenance of the colony were marked by a necropolitics, which will be the specter that will haunt those lands up until this day. That specter of death, however, will not entirely obliterate the other, for according to the spectral logic the specter always returns. Thus, the entire genocide, which further extended to an ethno-epistemicide, did not destroy ancestry altogether. The power of the ancestry of those indigenous and African peoples resists those ghosts from the colony in spectral fashion. 
The colonies did not realise the might of the specters that move the world, be it the potency of ancestry or the power of the happening. And what they had not expected was that a happening was to come, that is, that that continent's division in nation-states would create new peoples, and that some of them would resist, taking over their African, indigenous, and European inheritances. Resisting the dominant elites that wanted and still want to make those lands a new Europe, together with the popular classes, black, indigenous, and mestizo men and women would not allow the predominance of the white European's mythological discourse of purity. In other words, they resist up until today, conjuring the ghosts of the colony, making the colonizer's language, religions, cultures, and sciences quiver. In light of this, the countries of the so-called Global South have become the colonizer's specter.

Europe's modernization would not have been possible without colonization, without the kidnapping, enslavement, rape and murder of America's and Africa's multiple societies. That colonization aimed at strengthening even more the European spirit. However, they did not count on colonization becoming a specter-forging machine that would haunt them back. Hence, just as the discourse of bringing development and progress to those societies is a myth - specters concealing an ethnic and racial violence aiming at profit and power - so to the discourse that those peoples would not fight back and resist colonial violence, accepting it peacefully, is yet another myth. One therefore must address the specters that were conjured, the specters of struggles, battles, revolutions, and insurrections that have haunted and terrorized the Europeans. Those specters have been forged in resistances in Haiti, Brazil, Peru, Bolivia and in every country making up that which is violently called America (a spectral name that attempts to homogenize an almost incalculable multiplicity of differences).

In terms of resistances, we would like to conjure a specific specter, that of the Palmares State, known as Quilombo dos Palmares, which was situated at the Barriga Mountain, in the Brazilian state of Alagoas. Perhaps we can venture to say that Quilombo dos Palmares was the first democratic state, premised on the rule of law, in the Americas, founded in the XVI century, around 1594, and withstanding until 1694, with up to 20 thousand inhabitants. Palmares was the first and most feared specter that haunted and terrorized the Portuguese colonial state.

Quilombo dos Palmares was brought into existence by the enslaved black men and women who fought slavery and the racist Portuguese colonial system. The State of Palmares was a threat to the Portuguese Empire for several reasons, thus becoming the colonial empire's great enemy. Feeling thus threatened on top of a wounded narcissism, the Portuguese attacked Quilombo dos Palmares for years before achieving its complete destruction and the death of their great leader, Zumbi. Notwithstanding, that destruction did not come easily, for the palmarinos resisted for years thanks to their strong army and a tremendous military strategic mentality.

However, the threats to the Portuguese Empire did not exist solely by virtue of the palmarinos' strong military power and strategies. The palmarinos' capacity for political and economic self-management, maintenance and sustainability deeply pestered the Empire. 
Furthermore, the great horror for the Portuguese was that the revolution in Palmares was enacted in terms of a democratic system, within which everyone lived together, black, mestizo, indigenous and white peoples, under a logic of equality and solidarity. Palmares represented a modernity and an advancement that the Portuguese did not wish to grant to the black and indigenous peoples. Palmares held a strong capacity for management and autonomy without the need to rely on the Portuguese Empire, for they grew their own food, negotiated with farmers from nearby regions, practiced their own religion, and welcomed people fleeing the Empire's violence. In this sense, the Portuguese did not expect that the violence of slavery and racism would forge a strong people, a resistance. We should not forget orixá Ogun's lesson from the Iorubá people: it is in fire that one forges iron.

In believing that they were forging ghosts that would wander in the colonial world, the Portuguese did not expect that, from the violence of slavery, black men and women kidnaped from Africa would invoke their ancestry and make good on the African spirit once denied to them by Hegel and conjured by the Portuguese. Therefore, the power of the specter of African ancestry is so great, so potent, that black palmarinos' resistance and capacity for creation have served as inspiration to anti-racist struggles led by black men and women in social movements and universities, making good on their rights and on the recognition of their histories and relevance in the formation of Brazil. Accordingly, black men and women were of key importance to the histories of struggles against slavery and racism in racist-colonial-policial Brazil. We thereby summon the specters of indigenous and African ancestors, of Gangazumba, Zumbi, Dandara, Luiza Mahin, Beatriz Nascimento, Marielle Franco and of many other victims to the racist-colonial state (Gonzales 2018; Ratts 2006; Nascimento 2019). That they may return and haunt those who reinforced the specter of racism, particularly the specter of the myth of racial democracy that conceals what is produced in our society.

After both summoning and being haunted by specters, it is hard to speak of conclusions or of the closing of a text; for in finishing a text, in closing a book, we will consequently be haunted by a phalanx of specters. Nevertheless, Derrida teaches us that the encounter with specters begins in the very opening of a book. In his Specters of Marx, Jacques Derrida (1994b) already inaugurates the first page haunting us by bringing up the violence of racism, dedicating the book to the memory of Chris Hani, murdered in South Africa; and by bringing up the responsibility of the inheritance when invoking Shakespeare's Hamlet. Before a book so full of phantasmagoria, we welcome the inheritance of Specters of Marx, that which strengthens us as black, Latinxs, indigenous peoples and Brazilians to think the deconstruction of coloniality, starting from the conjuration of the colonial specter. 


\section{Notes}

1 [Note by Rodrigues] Some commentators call it the 'second Derrida' (Rappport 2002; Mitchell 2007). For numerous reasons that do not fit into this paper, I disagree with this division in its proposal to attribute a political philosophy to Derrida only from the 1990s onwards. However, I do recognize that, as a temporal mark, the division works for certain contextualisations, which is my interest here.

2 [Translator's note] In the original Portuguese that this paper was written in, there is no translation of hauntology that resembles the word 'ontology', although the English pairing ontology-hauntology has a different effect, as highlighted by the author.

3 [Translator's note] The neologism obsidiologia comes from the word obsídio, which is synonymous to surround oneself with something. However, it holds no resemblance to the Portuguese words for haunting or ontology.

4 [Note by Rodrigues] Skinner writes in a translator's note: 'Esclarecemos que, embora estejamos traduzindo desde o francês, é a forma verbal geht seguida de um, do original alemão, que está sendo traduzida, em português, por rondar, e não o verbo hanter. Não discutiremos, aqui, as acepções possíveis para hanter e hantisse, pois essas são, em parte, o tema desse livro. Limitaremo-nos a sugerir que, embora os dicionários francês-português distinguam duas acepções para hanter (1) frequentar; (2) obsedar, obsidiar; seria preciso dizer, como fará J. Derrida noutra parte neste ensaio, que "essa distinção é antes uma co-implicação." Assim, mantivemos o verbo rondar na primeira frase do Manifesto e traduzimos hanter por "obsidiar," hantise por “obsessão" e hantologie por "obsidiologia," em outras ocorrências' (Derrida 1994b: 18n1).

5 [Translator's note] In Portuguese, both espectrologia and assombrologia are neologisms. The first could be roughly translated as spectrology, and the latter would be equivalent to the meaning of hauntology (to haunt, in Portuguese, is to assombrar), although it loses the reference to ontology.

6 [Note by Rodrigues] Amongst the readers of Fisher in Brazil there is no consensus in relation to the translation of hantologie/hauntology, as you may see in the presentations of the 'Mark Fisher Coloquium - spectral realism' (http://bit.ly/2J93VZl). J. P. Caron, for example, uses espectrologia. I thank Gabriel Tupinambá for the interlocution in this non-translation task.

7 [Translator's note] In Portuguese, hauntológica/o is an adjectival neologism equivalent to hauntological.

8 [Note by Rodrigues] To Rafael Haddock-Lobo, the quasi-concept 'specter' is fundamental to comprehend the thought game of deconstruction, as a kind of amplification and dissemination of the notions of 'trace' and 'hinge,' present since Grammatology of 1967. Although present in a dispersed way throughout Haddock-Lobo's texts, this quasi-concept may be found more pointed fashion in the chapter 'Conjurar - o úmido' in his Para um pensamento úmido - a filosofia a partir de Jacques Derrida (2011), where he intended to delineate a 'logic' of specters such as Derrida presents them in Specters of Marx. The problem in spectral logic turns up as fundamental to comprehend the issue of 'experience' in Derridean thinking (see 'As aporias da experiência,' in Haddock-Lobo 2019b) and the issue of death and survival/living-on. The Derridean notion of 'specter' remains fundamental for the development of Haddock-Lobo's current research on coloniality and popular Brazilian philosophy.

9 [Translator's note] Quijano's citations are translated to English from the cited edition.

10 [Note by Rodrigues] Here, Fisher is utilizing the concept of post-colonial melancholia in Paul Gilroy (2005), thought of as a resentful refusal to accept the transformations imposed by colonization. In this resentment would be the search for politics to repair the past, which would keep the construction of a political future stuck to the lost object and, therefore, uncapable of inventing alternatives.

11 [Note by Rodrigues] Data from the Instituto de Segurança Pública show that the Military Police of Rio de Janeiro killed 434 people in confrontations in the first trimester of 2019, the largest number recorded since 1998. In the year prior, there were 368 deaths in the same period. See 'Número de mortes por intervenção policial no RJ é o maior nos últimos 20 anos' (Grandin and Rodrigues 2019).

12 [Note by Rodrigues] As Angela Davis (2003: 18-19) notes: 'The prison is one of the most important features of our image environment. This has caused us to take the existence of prisons for granted. The prison has become a key ingredient of our common sense. It is there, all around us. We do not question whether it should exist. It has become so much a part of our lives that it requires a great feat of the imagination to envision life beyond the prison.' 
13 [Note by Rodrigues] For an excellent discussion around the issues addressed by Butler and Spivak in this text, see Thais de Bakker's work (2018) and her original approach to the movements of congregation and segregation that constitute the nation-state's violence.

14 [Note by Haddock-Lobo] Jacques Derrida presented the lecture 'Forgiveness, Truth, Reconciliation: What Gender?' on 8 August 2004 at the Jacques Derrida International Colloquium: 'Towards a Reflection on Deconstruction: issues of politics, ethics and aesthetics', organized by Evando Nascimento of the Federal University of Juiz de Fora, and which took place at the Maison de France Theatre of Rio de Janeiro (see Derrida 2004, 2005).

\section{References}

Arendt, Hannah. 1970. On Violence. San Diego: Harcourt, Brace, Jovanovich.

Bakker, Thaís. 2018. O Estado-Nação a partir da filosofia de Judith Butler: reflexões sobre processos de congregação e segregação. Master thesis, Universidade Federal do Rio de Janeiro (UFRJ), Brazil.

Benjamin, Walter. 2011 [1921]. Escritos sobre mito e linguagem. Transl. Ernani Chaves. São Paulo: Editora 34 .

2005 [1940]. 'Sobre o conceito de história.' In Michael Lowy (ed), Walter Benjamin: aviso de incêndio: Uma leitura das teses "Sobre o conceito de história" de Walter Benjamin. 1st ed. Transl. Jeanne Marie Gagnebin and Marcos Lutz Muller. São Paulo: Boitempo Editorial, pp. 33-146.

Biteti, Mariane de Oliveira and Marcelo J D Moraes. 2019. 'Vidas e Saberes Periféricos como Potências Transgressoras.' Tlalli. Revista De Investigación En Geografía 2: 79-96.

Brown, Wendy. 1999. 'Resisting Left Melancholy’ boundary 226 (3): 19-27.

Butler, Judith and Gayatri Spivak. 2018. Quem canta o Estado-nação? língua, política, pertencimento. Transl. Vanderlei Zacchi and Sandra Goulart Almeida. Brasília: Editora Universidade de Brasília.

Davis, Angela. 2003. Are Prisons Obsolete? New York: Seven Stories Press.

Derrida, Jacques. 1982. Margins of Philosophy. Transl. Alan Bass. Chicago: Chicago University Press. 1992a. 'Before the Law. In Derek Attridge (ed), Acts of Literature. New York: Routledge, pp. 181-220.

1992b. The Other Heading: Reflections on Today's Europe. Transl. Pascale Anne Brault and Michael B. Naas. Bloomington: Indiana University Press.

1994a. Espectros de Marx: o estado da dívida, o trabalho do luto e a nova internacional. Transl. Anamaria Skinner. Rio de Janeiro: Ed. Relume Dumará.

. 1994b. Specters of Marx: The State of the Debt, the Work of Mourning, \& the New International. Transl. Peggy Kamuf. New York: Routledge.

1996. Le monolinguisme de l'autre ou la prothèse d’origine. Paris: Galilée.

2002 [1989]. 'Force of Law: The "Mystical Foundations of Authority.”' In Gil Anidjar (ed), Acts of Religion. New York: Routledge, pp. 228-298.

2004. 'Versöhnung, ubuntu, pardon: quel genre?' Le Seuil 43: 111-156.

2005. 'O perdão, a verdade, a reconciliação: qual gênero?' In Evando Nascimento (ed), Pensar a desconstrução. São Paulo: Estação Liberdade.

2007. Learning to Live Finally - the Last Interview. Transl. Pascale-Anne Brault and Michael Naas. New Jersey: Melville House Publishing. 
Fisher, Mark. 2009. Capitalist Realism: Is there no alternative? Washington: Zero Books.

2014. Ghosts of My Life: Writings on Depression, Hauntology and Lost Futures. Washington: Zero Books.

2018. Los fantasmas de mi vida - Escritos sobre deprisión, hauntología y futuros perdidos.

Transl. Fernando Bruno. Buenos Aires: Caja Negra.

Foucault, Michel. 2003 [1976]. Society Must Be Defended. Transl. David Macey. New York: Picador. 2007 [1978]. Security, Territory, Population. Transl. Graham Burchell. New York: Palgrave Macmillan.

Freud, Sigmund. 2019. O infamiliar [das Unheimliche] - Edição comemorativa bilíngue (1919-2019). Transl. Ernani Chaves and Pedro Heliodoro Tavares. Belo Horizonte: Autêntica.

Fukuyama, Francis. 1992. The End of History and the Last Man. New York: Free Press.

Gilroy, Paul. 2005. Postcolonial Melancholia. New York: Columbia University Press.

Gonzales, Lélia. 2018. Primavera para as rosas negras. São Paulo: UCPA Editora.

Grandin, Felipe and Matheus Rodrigues. 2019. 'Número de mortes por intervenção policial no RJ é o maior nos últimos 20 anos; apreensão de fuzis bate recorde em 2019.' G1 [online], 3 May. At https://glo.bo/2J7Iure [Accessed on 11 May 2020].

Haddock-Lobo, Rafael. 2011. Para um pensamento úmido. Rio de Janeiro: Nau Editora.

2019a. 'Derrida e a experiência colonial: Para o outro lado do Mediterrâneo e além.' Ensaios Filosóficos 19: 22-36.

2019b. Experiências abissais - ou sobre as condições de impossibilidade do real. Rio de Janeiro: ViaVerita.

2020. Fantasmas da colônia. Rio de Janeiro: Editora Ape'Ku.

Kafka, Franz. 2009. The Trial. Transl. Mike Mitchell. Oxford: Oxford University Press.

. 2012. 'Before the Law.' In Nahum Norbert Glatzer (ed), The Complete Stories. Transl. Willa and Edwin Muir. New York: Knopf, pp. 3-4.

Mbembe, Achille. 2018. Necropolítica: biopoder, soberania, estado de exceção, política de morte. Transl. Renata Santini. N1-Edições: São Paulo.

Mitchell, W. J. T. and Arnold I. Davidson. 2007. The Late Derrida. Chicago: University of Chicago Press.

Moraes, Marcelo. 2018. Democracias espectrais: uma abordagem a partir de Jacques Derrida. PhD thesis. Universidade do Estado do Rio de Janeiro (UERJ), Brazil.

Moraes, Marcelo José Derzi. 2019. 'A filosofia ubuntu e o quilombo: a ancestralidade como questão filosófica.' Revista África e Africanidades 32: n.p.

2020. 'Becos, ruas, marquises e esquinas.' In Rafael Haddock-Lobo (ed), Encruzilhadas Filosóficas. Rio de Janeiro: Editora Ape’Ku.

Nascimento, Abdias. 2019. Quilombismo. São Paulo: Perspectiva.

Nietzsche, F. 2003. Segunda consideração intempestiva - da utilidade e desvantagem da história para a vida. Transl. Marco Antônio Casanova. Rio de Janeiro: Relume Dumará.

Quijano, Aníbal. 2014 [2001]. ‘El fin de cual historia?’ In Danilo Assis Clímaco (ed), Cuestiones y horizontes: de la dependência histórico-estructural a la colonialidad/descolonialidad del poder. Buenos Aires: CLACSO. 
2014 [2001]. 'El regresso del futuro y las cuestiones del conocimiento.' In Danilo Assis Clímaco (ed), Cuestiones y horizontes: de la dependência histórico-estructural a la colonialidad/descolonialidad del poder. Buenos Aires: CLACSO.

2014 [2001]. 'Colonialidad del poder, eurocentrismo y América Latina.' In Danilo Assis Clímaco (ed), Cuestiones y horizontes: de la dependência histórico-estructural a la colonialidad/descolonialidad del poder. Buenos Aires: CLACSO.

Rapaport, Herman. 2002. Later Derrida: Reading the Recent Work. New York and London: Routledge. Ratts, Alex. 2006. Eu sou atlântica. sobre a trajetória de vida de Beatriz Nascimento. São Paulo: Imprensa Oficial do Estado de São Paulo.

Tupinambá, Gabriel. 2018. 'A vida dos fantasmas na periferia do mundo.' Paper delivered at Colóquio Mark Fisher: Realismo Espectral. Rio de Janeiro, Brazil, 24-25 August.

\section{About the authors}

Carla Rodrigues is Professor of Ethics of the Department of Philosophy of the Federal University of Rio de Janeiro (UFRJ), where she is also researcher in the Postgraduate Program of the Institute of Philosophy and the Social Sciences. She has focused on the study of the thought of Judith Butler. She is recipient of a productivity fellowship from FAPERJ for the project 'Judith Butler: do gênero à crítica da violência de estado' (Judith Butler: From Gender to the Critique of State Violence). She is member of the research area 'Gender, race and coloniality' in the Postgraduate Program in Philosophy and directs the laboratory Filosofias do tempo do agora, which is catalogued in the Directory of Research Groups of CNPq. She received her doctorate and masters degree from the Pontifical Catholic University of Rio de Janeiro.

Rafael Haddock-Lobo is professor in the Department of Philosophy and the Postgraduate Program in Bioethics, Applied Ethics and Collective Health at the Federal University of Rio de Janeiro (UFRJ), and professor in the Postgraduate Program in Philosophy at the State University of Rio de Janeiro (UERJ). He authored Da existência ao infinito: ensaios sobre Emmanuel Lévinas (Loyola/PUC-Rio, 2005), Derrida e o labirinto de inscrições (Zouk, 2009), Para um pensamento úmido: a filosofia a partir de Jacques Derrida (NAU/PUC-Rio, 2011) e Experiências abissais ou sobre as condições de impossibilidade do real (Via Verita, 2019). He directs the Laboratório 'X' de encruzilhadas filosóficas (IFCS-UFRJ/CNPq), the Encruzilhadas Seminar and the book series Coleção X published by Editora Ape'Ku. His most recent book is Os fantasmas da colônia: notas de desconstrução e filosofia popular brasileira (Ape'Ku, 2020).

Marcelo José Derzi Moraes received a doctorate in Philosophy from the State University of Rio de Janeiro (UERJ). He is assistant professor in the Department of Education of the Faculdade de Formação de Professores at UERJ. He directs the research project 'Por uma filosofia descolonial' (Toward a Decolonial Philosophy) and the extension project 'Ressonâncias descoloniais em Filosofia e Educação' (Decolonial Resonances in Philosophy and Education). 


\section{Espectros da Colonialidade: Um Fórum sobre os Espectros de Marx de Jacques Derrida depois de 25 anos, Parte V}

Resumo: Jacques Derrida entregou a base de os Espectros de Marx: O Estado da Dívida, a Obra do Luto e a Nova Internacional como discurso plenário na conferência 'Whither Marxism?', na Universidade da Califórnia, em Riverside, em 1993. A versão mais longa do livro foi publicada em francês no mesmo ano e em inglês e português no ano seguinte. Uma década após a publicação dos Espectros, as análises de Derrida provocaram uma grande literatura crítica e convidaram tanto a consternação quanto a celebração de figuras como Antonio Negri, Wendy Brown e Frederic Jameson. Este fórum procura estimular novas reflexões sobre Derrida, desconstrução e Espectros de Marx, considerando como futuro do passado anunciado pelo livro se saiu depois de um movimentado quarto de século. Neste quinto grupo de contribuições, três filósofos exploram os espectros da colonialidade, os legados especificamente brasileiros da colonialidade portuguesa e europeia. Carla Rodrigues abre o diálogo explorando a assombração e a melancolia provocada pelas formas coloniais de violência e mostra como o confronto com a necropolítica brasileira sustenta o legado derridiano; Rafael Haddock-Lobo faz uma meditação sobre as dificuldades de estar perante a lei e de estar diante de espectros como um meio de ser justamente assombrado pelos outros da filosofia europeia no Brasil; finalmente, Marcelo Moraes continua o tema da Europa como uma máquina de produção de espectros e invoca especificamente as presenças das resistências políticas indígenas e afro-brasileiras com o objetivo de desconstruir a colonialidade.

Palavras-chave: Derrida, Jacques; Brasil; tradução; violência; necropolítica; Kafka, Franz; filosofia; raça; colonialidade; quilombos.

Received on 10 January 2020, and approved for publication on 12 May 2020.

https://creativecommons.org/licenses/by-nc/4.0/ 